\title{
transLateris MPTE
}

\begin{abstract}
nglish-speaking scholars do not have a single set of conventions for the rendering of ancient Egyptian and modern Arabic personal and place names. Most of the names mentioned in this book occur in two standard reference works: John Baines and Jaromír Málek, Atlas of Ancient Egypt (New York, 1980), and Civilizations of the Ancient Near East, edited by Jack M. Sasson (New York, 1995). Wherever possible, the renderings of Egyptian and western Asian names follow the usages in those volumes. The only exception is the omission of the typographical sign for ayin; this consonant does not exist in English, and it was felt that its inclusion would serve only as a distraction.

The brief quotations from the poetry of Rilke are cited from Rainer Maria Rilke, Duino Elegies, translated by David Young (New York, 1978).

This volume fills the need for a concise history of pharaonic Egypt, both for general readers and for use in the classroom, and I am grateful to Cornell University Press for asking me to serve as its translator. I also thank Erik Hornung and Eckhard Eichler for their help and encouragement during the course of this project.
\end{abstract}

D. L. 
